Jovana Jestrović ${ }^{1}$
Centar za podršku
ranom razvoju
i porodičnim
odnosima
Harmonija, Novi Sad

\section{Ivana Mihić}

Odsek za

psihologiju,

Filozofski fakultet, Univerzitet u Novom Sadu

\section{SOCIJALNA PODRŠKA I STRES POVODOM NEPLODNOSTI2: ZNAČAJNOST RAZLIČITIH IZVORA PODRŠKE ${ }^{3}$}

Rezultati ranije sprovođenih istraživanja ukazuju na značaj socijalne podrške za kvalitet života pojedinca. Socijalna podrška izdvaja se kao jedan od najvažnijih protektivnih faktora u procesu suočavanja sa brojnim životnim krizama, od kojih je jedna i neplodnost. $U$ cilju ispitivanja značajnosti dobijene socijalne podrške od strane prijatelja, porodice i značajne osobe u percepciji stresa povodom neplodnosti, ispitano je 312 žena, starosti od 21 do 48 godina, koje se suočavaju sa neplodnošću. $\mathrm{Na}$ ispitanicama je primenjena Multidimenzionalna skala percipirane socijalne podrške i Upitnik problema sa plodnošću. Ispitanice socijalnu podršku koju primaju od najbližijih procenjuju veoma zastupljenom, pri čemu se pokazalo da ispitanice najviše zastupljenom procenjuju podršku od značajne osobe, zatim porodice i na kraju prijatelja. Uzimajući u obzir dužinu suočavanja sa problemom, odnosno grupu u kojoj se ispitanice nalaze, dobijene su značajne razlike u percepciji podrške od strane porodice i prijatelja, ali ne i partnera. Nadalje, bez obrzira na najveću zastupljenost podrške od strane partnera, primenom regresione analize dobijeno je da smanjenju percipiranog stresa povodom neplodnosti u značajnoj meri doprinose podrška od strane prijatelja i porodice, dok se ova vrsta podrške od strane značajne osobe nije pokazala značajnim prediktorom, izuzev u domenu stresa koji se odnosi na partnerski odnos. Dobijeni nalazi ukazuju na značaj edukovanja

2 Prema kliničkoj definiciji, sterilitet podrazumeva biološku nemogućnost začeća i ostvarivanja potomstva nakon najmanje godinu dana redovnih seksualnih odnosa, bez korišćenja kontraceptivnih sredstava, dok se neplodnost odnosi na nemogućnost iznošenja trudnoće do kraja (Zegers-Hochschild et al., 2009). S obzirom na to da je polovina ispitanica iz sprovedenog istraživanja nekad ostvarila trudnoću, ali ne i iznela do kraja, termin koji će biti korišćen je neplodnost.

3 Rad je nastao u okviru projekta „Efekti egzistencijalne nesigurnosti na pojedinca i porodicu u Srbiji“ (179022) koji podržava Ministarstvo prosvete, nauke i tehnološkog razvoja Republike Srbije, a čiji je nosilac Filozofski fakultet, Novi Sad. 
šire populacije o problemu neplodnosti i načinima pružanja podrške ovim parovima, kao i rad sa pojedincima i parovima na razvijanju strategija za traženje podrške od bliskih ljudi.

Ključne reči: neplodnost, partner, porodica, prijatelji, socijalna podrška 


\section{Uvod}

Socijalna podrška definiše se kao percepcija pojedinca o dostupnosti osobe od poverenja i postojanju ponašanja koja uključuju brigu od strane drugih ljudi, najčešće od strane partnera, porodice ili prijatelja (Walen \& Lachman, 2000). Kao takva, socijalna podrška može redukovati negativne uticaje brojnih životnih stresora na pojedinca (Schwarzer \& Knoll, 2007). Pored značaja u prevladavanju brojnih drugih životnih stresora, socijalna podrška predstavlja kritičnu komponentu u procesu prilagođavanja na stres povodom neplodnosti, naročito kod žena, s obzirom na to da su one te koje o problemu neplodnosti sa drugim ljudima ipak govore u većoj meri u odnosu na muškarce (Slade et al., 2007).

U društvu u kom je fertilitet normativ i u kom se podrazumeva da će se svi parovi reprodukovati i imati potomstvo, oni koji ne mogu da se ostvare u roditeljskoj ulozi često osećaju sramotu povodom svoje dijagnoze, što dovodi do toga da se kod njih razvija ideja o tome kako je bolje kriti sve što je povezano sa ovim problemom. Ponašajući se na ovaj način, želeći da zaštite sebe i partnera, ovi parovi se, paradoksalno, susreću sa nemogućnošću dobijanja adekvatne socijalne podrške (Abraham, 2019). S obzirom na to da je neplodnost kriza koja pogađa pojedinca, ali i par (Burns \& Covington, 2006), osnovna ideja socijalne podrške uključuje partnere kao primarni izvor podrške jedno drugome (Kroemeke \& Kubicka, 2018). U skladu sa navedenim, rezultati sprovođenih istraživanja potrđuju da su žene u nošenju sa problemom neplodnosti okrenute svojim muževima. Ipak, prema rezultatima istraživanja, žene o problemu neplodnosti i emocijama koje se javljaju razgovaraju isključivo sa svojim muževima, što ih, bez obzira na značajnost postojanja podrške među partnerima, sa druge strane dovodi do izostanka adekvatnog sistema podrške u nošenju sa problemom (Woods et al., 1991). U tradicionalnim društvima, u koje spada i naše društvo, makar kada se govori o temi porodice i roditeljstva, parovi koji se suočavaju sa neplodnošću mogu se osećati izolovano. Osećaj izolovanosti može se objasniti izostankom iskustava koje mogu deliti sa prijateljima i porodicama porekla, što neretko dovodi do izbegavanja određenih aktivnosti od strane para, posebno onih aktivnosti koje uključuju decu (Peterson et al., 2012). Posledice suočavanja sa ovim problemom, koje se kreću od emocionalnih i psiholoških problema, do socijalne stigme, u društvu u kom je i dalje osnovna uloga žene da bude majka (Kričković Pele i Beker, 2014), iako se odražavaju na funkcionisanje oba člana para, i dalje u većoj meri pogađaju žene (Saleem et al., 2019). Iako rezultati istraživanja ukazuju na to da je usamljenost i kod muškaraca i kod žena koji se suočavaju sa neplodnošću viša nego na normativnom uzorku (Knight et al., 1988), usamljenost kod žena sa ovim problemom je izraženija nego kod muškaraca i obrnuto je proporcionalna percipiranoj socijalnoj podršci (Jirka et al., 1996). Usled izostanka postojanja bliskih osoba sa kojima mogu podeliti osećanja i razmišljanja o problemu sa kojim se suočavaju, te osećaja socijalne izolovanosti, povećava se vulnerabilnost i 
javljaju se problemi u domenu mentalnog zdravlja. U tom smislu, dobijeni nalazi ukazuju na značaj postojanja socijalne podrške kao protektivnog faktora u procesu nošenja sa stresom povodom neplodnosti (Saleem et al., 2019). Prema rezultatima ranije sprovođenih istraživanja uloga socijalne podrške ogleda se $u$ redukovanju osećanja izolovanosti kod ljudi koji se suočavaju sa neplodnošću (Martins et al., 2011), smanjenju stresa povodom neplodnosti (Hinton et al., 2010), a ističu i ulogu socijalne podrške kao protektivnog mehanizma u odnosu između stresa povodom neplodnosti i simptoma koji se manifestuju u domenu fizičkog (Welbourne et al., 2009) i mentalnog zdravlja (Martins et al., 2011; Saleem et al., 2019). Pored navedenog, efekat socijalne podrške nije vidljiv samo u smanjenju potencijalnih negativnih efekata koji se mogu javiti kao posledica suočavanja sa neplodnošću - o značaju postojanja adekvatne socijalne podrške govore i istraživanja u kojima se ona izdvaja kao važan faktor za postraumatski rast (Yu et al., 2014). Nadalje, osim dokazanog pozitivnog efekta u vidu niže procenjene depresivnosti i višeg nivoa životne svrhe kod žena koje se suočavaju sa ovom krizom, muževi žena koje socijalnu podršku percipiraju zastupljenijom govore o nižim nivoima depresivnosti, dok ženin nivo depresivnosti nije povezan sa nivoom podrške koju percipira njen suprug (Kroemeke \& Kubicka, 2018). Upravo navedeni nalaz govori o značaju ispitivanja primljene socijalne podrške kod žena koje se suočavaju sa problemom neplodnosti, budući da, osim toga što predstavlja značajan faktor u očuvanju svog mentalnog zdravlja, primljena socijalna podrška pozitivno doprinosi i mentalnom zdravlju njihovih partnera. Dobijeni nalazi mogu se objasniti činjenicom da su žene te koje ostvaruju više benefita od socijalne podrške. Žene su te koje više brinu o drugima i očekuju da drugi brinu o njima, te i u kontekstu neplodnosti njihova potreba za podrškom raste sa dužinom suočavanja (Jirka et al., 1996). Nadalje, kako su žene sklonije oslanjanju na socijalnu podršku kao vid suočavanja sa stresom, rezultati istraživanja pokazuju da su žene te koje procenjuju da je prisutnija socijalna podrška i pozitivne interakcije sa okolinom, nego što to procenjuju muškarci (Gerrity, 2001), dok je u nekim studijama i pokazano da percipirana socijalna podrška raste sa dužinom suočavanja sa problemom, tj. trajanjem braka (Ekinci et al., 2017). Takođe, s obzirom na to da muškarci svoju ulogu definišu više instrumentalno, više blagostanje i generalno bolje mentalno zdravlje kod muškaraca, može se objasniti zadovoljstvom koje osećaju povodom pružanja podrške svojim suprugama, koju one percipiraju značajnom (Kroemeke \& Kubicka, 2018).

Istraživanja pokazuju da se žene bolje prilagođavaju na stres povodom neplodnosti ukoliko percipiraju dostupnom podršku iz različitih resursa, kao što je podrška od strane porodice ili prijatelja (Martins et al., 2011). Nadalje, pored pozitivnih efekata koje ostvaruje visoka zastupljenost socijalne podrške, neke studije ukazuju na to da se u maloj meri zastupljena podrška od strane porodice pokazala prediktorom završetka tretmana posle godinu dana, kako kod muškaraca, tako i kod žena (Vassard et al., 2012). U nekim drugim istraživanjima podrška porodice izdvaja se kao značajan faktor na ženskom, 
ali ne i na muškom uzorku (Martins et al., 2014), što se može objasniti većom emocionalnom involviranošću žena u porodicu porekla, te većom potrebom i traženjem podrške, nego što je to slučaj kod muškaraca (Cousineau \& Domar, 2007). Rezultati nekih istraživanja ukazuju na izostanak značajnosti podrške prijatelja u snižavanju globalnog stresa povodom neplodnosti, ali se ovaj vid podrške i dalje pokazuje značajnim uzimajući u obzir pojedinačne aspekte stresa, pa tako ostvaruje značajan indirektni efekat na socijalni stres povodom neplodnosti (Martins et al., 2014). Izostanak značajnosti ove vrste podrške može se objasniti činjenicom da se radi o iskustvu sa kojim se ne susreću svi parovi, što dovodi do toga da oni koji se suočavaju sa neplodnošću podršku prijatelja koji nemaju problem sa začećem mogu smatrati neadekvatnom (Slade et al., 2007).

Pored podrške porodice i prijatelja, značajnom se ističe i podrška partnera, koja je u negativnoj korelaciji sa stresom, pa tako oni koji imaju doživljaj da ih partner više podržava doživljavaju stres nižim (Matsubayashi et al., 2004; Ying et al., 2015), a u nekim istraživanjima se ovaj faktor izdvaja najznačajnijim prediktorom, značajnijim od podrške od strane proširene porodice (Martins et al., 2014). Navedeni rezultat nije iznenađujuć, budući da se bračni odnos posmatra kao jedan od primarnih izvora podrške prilikom suočavanja sa stresom (Walen \& Lachman, 2000). Osim pozitivnih efekata na pojedinca, u istraživanju sprovedenom u našoj zemlji dobijena je pozitivna povezanost percipirane podrške od strane partnera sa procenjenom bračnom funkcionalnošću (Jestrović i sar., 2016).

U definisanju problema istraživanja ključnu ulogu su imali rezultati prethodnih studija o postojanju protektivne uloge socijalne podrške koja dolazi iz različitih resursa kod žena koje se suočavaju sa neplodnošču (Hinton et al., 2010; Martins et al., 2011; Welbourne et al., 2009), kao i oni koji ukazuju na udeo podrške percipirane od strane žena u mentalnom zdravlju njihovih partnera (Kroemeke \& Kubicka, 2018). U skladu sa tim, osnovni problem sprovedenog istraživanja odnosi se na ispitivanje uloge koju socijalna podrška od porodice, prijatelja i značajne osobe ima u percepciji globalnog stresa kod žena koje se suočavaju sa neplodnošću, kao i njegovih specifičnih domena. Pored toga, u istraživanju je ispitano i da li postoje razlike u percipiranoj socijalnoj podršci s obzirom na pripadnost ispitanica jednoj od tri grupe formirane na osnovu dužine suočavanja sa problemom (Ekinci et al., 2017), kao i s obzirom na to da li je nosilac dijagnoze ispitanica, njen suprug, oboje ili dijagnoza nije definisana, pa je uzrok neplodnosti nepoznat. Budući da su žene koje se suočavaju sa neplodnošću generalno sklonije traženju socijalne podrške od svojih partnera (Cousineau \& Domar, 2007), u izostanku studija koje uključuju navedeni faktor, autore je zanimalo da li postoje razlike u percepciji podrške u zavisnosti od toga ko je nosilac tretmana.

Na značajnost sprovedenog istraživanja ukazuje i činjenica da, bez obzira na prepoznavanje značaja i rast broja istraživanja koja se bave psihološkim aspektima neplodnosti, u Srbiji i dalje ne postoji istraživanje koje se bavi 
značajnošću socijalne podrške u procesu suočavanja sa ovom krizom. Nadalje, izučavanje socijalne podrške značajno je i u kontekstu podatka da se svaki šesti par u našoj zemlji suočava sa neplodnošću, što ukazuje na to da vrlo verovatno svaki građanin naše zemlje u svom okruženju ima makar jednu osobu koja ima teškoće sa začećem, što pred njega stavlja izazov pružanja adekvatne socijalne podrške istoj.

\section{Metod}

\section{Uzorak i procedura}

U istraživanju je učestovalo 312 žena, starosti od 21 do 48 godina $(M=$ 35.11; $S D=5.51$ ). Uslov za učešće u istraživanju bio je da nemaju dece, tj. da se suočavaju sa primarnim infertilitetom. Ispitanice su u braku od 0 do 25 godina $(M=7.64 ; S D=4.44)$, dok u proseku nešto više od 5 godina pokušavaju da ostvare potomstvo $(M=5.23 ; S D=4.08)$. Ispitanice su na osnovu dužine suočavanja sa neplodnošću (pitanja „Od kada pokušavate da imate decu?" i „Kada ste saznali da imate teškoće vezane za ostvarivanje roditeljske uloge?") podeljene u tri grupe i to tako da su u prvu grupu svrstane one koje se suočavaju sa problemom od 0 do 2 godine, u drugu grupu one koje se suočavaju sa problemom od 2 do 5 godina i u treću grupu one koje se suočavaju sa problemom preko 5 godina (Gerrity, 2001). Na osnovu ovakve podele, od ukupnog broja ispitanica njih 75 svrstano je u prvu, 118 u drugu i 119 u treću grupu.

$\mathrm{Na}$ ispitanom uzorku najčešće je nosilac dijagnoze žena (32.7\%), dok je otprilike u jednakom procentu nosilac dijagnoze muškarac $(21.4 \%)$, oboje $(23.6 \%)$ ili nije poznato $(22.3 \%)$. Polovina ispitanica je nekada bila trudna, ali trudnoća nije izneta do kraja. Najveći broj ispitanica ima završenu visoku školu ili fakultet (57.3\%), zatim srednju školu (32.7\%), magistraturu ili doktorat $(8.3 \%)$, dok najmanje njih ima završenu osnovnu školu (1.7\%). Najveći procenat živi u većem gradu (54.2\%), manjem gradu (32.1\%) i najmanje na selu $(13.8 \%)$. Procenat ispitanica koje svoje prihode procenjuju prosečnim je najveći i iznosi $75.6 \%$, njih sledi $16 \%$ ispitanica koje imaju prihode iznad i 8.3\% ispod proseka. Više od polovine ispitanica izjasnilo se da im je religija važna (64.3\%), 18.8\% nema stav prema religiji, dok za njih 16.9\% religija nije važna.

Pre sprovođenja istraživanja dobijena je dozvola za istraživanje od strane Etičke komisije Odseka za psihologiju Filozofskog fakulteta u Novom Sadu. Nakon dobijanja dozvole uz pomoć Google forms platforme kreirana je baterija upitnika koja je podeljena u Facebook grupama koje za temu imaju razmenu iskustava povodom suočavanja sa neplodnošču. Pre pristupanja istraživanju, svaka od ispitanica dala je saglasnost za učešće, nakon čega su pristupile popunjavanju upitnika. U informisanoj saglasnosti naglašeno je da se istraživanje anonimno i da će podaci biti korišćeni isključivo u naučne svrhe. S obzirom da 
je predmet istraživanja bila kriza sa kojom se ispitanice aktuelno suočavaju, ponuđeno im je da se obrate za psihološku podršku nekom od članova tima, što nijedna od ispitanica nije učinila.

\section{Instrumenti}

\section{Multidimenzionalna skala percipirane socijalne podrške (Multidimen- sional Scale of Perceived Social Support; MPSS)}

Multidimenzionalna skala percipirane socijalne podrške (MPSS; Zimet et al., 1988) je namenjena merenju percepcije adekvatnosti socijalne podrške od strane porodice, prijatelja i značajnih drugih. U istraživanjima sprovođenim u inostranstvu, koja su se bavila ispitivanjem percipirane socijalne podrške u kontekstu neplodnosti, skor na subskali koja se odnosi na podršku značajnih drugih uglavnom je uziman kao pokazatelj podrške od strane partnera (Martins et al., 2011), te je isto razumevanje primenjeno i prilikom interpretacije rezultata ovog istraživanja. U prilog tome dodatno ukazuje i podatak da većina žena u procesu suočavanja sa neplodnošću svog partnera vidi kao najvažniji izvor podrške (Kroemeke \& Kubicka, 2018), na osnovu čega se može pretpostaviti da su i ispitanice koje su učestovale u ovom istraživanju odgovarajući na pitanja u okviru subskale koja se odnosi na podršku značajne osobe (npr. „U mom životu postoji posebna osoba kojoj je stalo do toga kako se ja osećam.") zapravo procenjivale podršku partnera. Celokupna skala se sastoji od 12 ajtema uz koje je priložena sedmostepena Likertova skala (1 - u potpunosti se ne slažem; 7 - u potpunosti se slažem). Pouzdanost izražena Kronbahovim alfa koeficijentom $\mathrm{u}$ stranim istraživanjima kreće se od .81 do .94, u zavisnosti od subskale (Zimet et al., 1990). Pouzdanost celokupne skale u stranim istraživanjima iznosi .93 (Canty-Mitchel \& Zimet, 2000), dok u sprovedenom istraživanju iznosi .94. Pouzdanost pojedinačnih subskala u sprovedenom istraživanju je visoka i to: porodica - .94; prijatelji - .94 i značajna osoba - .91.

\section{Upitnik problema sa plodnošću (Fertility Problem Inventory; FPI)}

Primenjeni upitnik (Fertility Problem Inventory, FPI; Newton et al., 1999) meri distres, uverenja i stavove u vezi sa neplodnošću. Osnovna prednost ovog upitnika ogleda se u njegovoj specifičnosti, s obzirom na to da su se neke od zamerki prethodno sprovođenim istraživanjima odnosile na nedovoljne specifičnosti instrumenata kojima je procenjivan nivo stresa kod ispitanika (Newton et al., 1999). Celokupan upitnik sastoji se od 46 ajtema koji mere nivo doživljenog stresa u vezi sa sterilitetom. Sastoji se od 5 subskala, a to su: Socijalni aspekt, Seksualni aspekt, Partnerski odnos, Potreba za roditeljstvom i Odbijanje života bez dece, uz koje je za odgovaranje priložena Likertova skala (1 - uopšte se ne slažem; 6 - u potpunosti se slažem). U sprovedenom 
istraživanju korišćen je sumacioni skor, odnosno globalni nivo stresa, kao i njegovi specifični domeni. Na stranom uzorku pouzdanost instrumenta u celini je bila visoka i izražena kroz vrednost Kronbahovog alfa koeficijenta iznosila je .93 (Newton et al., 1999), a ista vrednost alfa koeficijenta dobijena je i u sprovedenom istraživanju. Pouzdanost pojedinačnih skala je takođe visoka i kreće se od .78 za Seksualni aspekt, do .87 za Potrebu za roditeljstvom.

\section{Rezultati}

\section{Deskriptivni pokazatelji}

Na sve tri subskale skale za merenje percipirane socijalne podrške ispitanice imaju visoke skorove, pri čemu socijalnu podršku od strane značajne osobe procenjuju najviše zastupljenom, zatim podršku od strane porodice, dok je najmanje zastupljena podrška prijatelja. Procenjeni nivo globalnog stresa povodom neplodnosti kreće se oko teorijske aritmetičke sredine, dok je stres najniži u domenu partnerskog odnosa, a najviši prosečan skor ispitanice imaju na subskali koja se odnosi na odbijanje života bez dece (Tabela 1).

Tabela 1

Deskriptivni pokazatelji za globalni stres povodom neplodnosti, njegove specifične aspekte i različite resurse socijalne podrške

\begin{tabular}{lcccccc}
\hline & Min & Max & $M$ & $S D$ & $S k$ & $K u$ \\
\hline Globalni stres povodom neplodnosti & 1.30 & 5.15 & 3.26 & 0.85 & 0.00 & -0.57 \\
Socijalni aspekt & 1.00 & 5.80 & 2.96 & 1.13 & 0.29 & -0.67 \\
Seksualni aspekt & 1.00 & 5.75 & 2.73 & 1.13 & 0.39 & -0.56 \\
Partnerski odnos & 1.00 & 5.60 & 2.37 & 1.03 & 0.90 & 0.33 \\
Potreba za roditeljstvom & 1.00 & 6.00 & 3.80 & 1.28 & -0.23 & -0.84 \\
Odbijanje života bez dece & 1.30 & 6.00 & 4.44 & 1.05 & -0.78 & 0.07 \\
Socijalna podrška - total & 1.00 & 7.00 & 5.68 & 1.37 & -1.42 & 1.64 \\
Socijalna podrška - porodica & 1.00 & 7.00 & 5.62 & 1.65 & -1.20 & 0.45 \\
Socijalna podrška - prijatelji & 1.00 & 7.00 & 5.49 & 1.65 & -1.22 & 0.69 \\
Socijalna podrška - značajna osoba & 1.00 & 7.00 & 5.93 & 1.50 & -1.70 & 2.13 \\
\hline
\end{tabular}

Napomena. Min - minimalna vrednost; Max - maksimalna vrednost, $M$ aritmetička sredina; $S D$ - standardna devijacija; $S k$ - mera zakošenosti distribucije; $K u$ - mera spljoštenosti distribucije.

Značajnost razlika u percepciji različitih izvora socijalne podrške testirana je t-testom za zavisne uzorke, pri čemu je potvrđeno postojanje značajnih razlika između podrške od strane bliske osobe i podrške od prijatelja i porodice, 
dok u percipiranoj podršci između ova dva izvora nije dobijena značajna razlika (Tabela 2). Dobijeni nalazi ukazuju na to da žene podršku od strane partnera percipiraju značajno prisutnijom i u odnosu na podršku dobijenu od prijatelja i u odnosu na podršku porodice.

Tabela 2

Značajnost razlika među različitim izvorima podrške

\begin{tabular}{lcccccc}
\hline & $N$ & $M$ & $S D$ & $t$ & $d f$ & $p$ \\
\hline porodica: prijatelji & 309 & .13 & 1.58 & 1.51 & 308 & .13 \\
porodica : značajna osoba & 306 & -.30 & 1.34 & -3.94 & 305 & .00 \\
prijatelji : značajna osoba & 306 & -.44 & 1.31 & -5.81 & 305 & .00 \\
\hline
\end{tabular}

Napomena. $N$ - broj ispitanica; $M$ - aritmetička sredina; $S D$ - standardna devijacija; $t$ - vrednost t-testa za zavisne uzorke; $d f$ - stepeni slobode; $p$ - nivo značajnosti.

\section{Značajnost faktora nosioca dijagnoze i dužine suočavanja sa neplo- dnošću u percipiranoj socijalnoj podršci}

Primenom analize varijanse testirana je značajnost faktora koji se odnosi na nosioca dijagnoze unutar para u percepciji podrške od strane porodice, prijatelja i partnera. Dobijeni nalazi ukazuju da ovaj faktor nije značajan ni u slučaju podrške od strane porodice, $F(3,306)=.70 ; p=.55$, prijatelja, $F(3,306)$ $=.32 ; p=.81$, ni značajne osobe, $F(3,303)=.16 ; p=.93$. Dakle, razlike u percipiranoj podršci iz sva tri ispitivana domena ne postoje, bez obzira na to da li je nosilac dijagnoze ispitanica, njen suprug, oboje ili nije poznato.

Ispitujući efekat grupe u kojoj se ispitanice nalaze (svrstane po dužini suočavanja sa problemom) značajne razlike se dobijaju u percepciji podrške od strane porodice i prijatelja, ali ne i u percepciji podrške od strane partnera (Tabela 3). Razlike dobijene u domenu podrške od strane porodice prikazane su na Grafiku 1, dok su razlike u domenu podrške od strane prijatelja prikazane na Grafiku 2. U slučaju oba resursa podrške, ona je najviša kod prve grupe ispitanica, najniža je u drugoj grupi, dok je prisutan blagi porast u trećoj grupi u odnosu na drugu, ali i dalje nije jednako visoko procenjivana kao u slučaju ispitanica koje se najkraće suočavaju sa problemom, svrstanih u prvu grupu. Takođe, u slučaju podrške prijatelja, ispitanice iz treće grupe ostvaruju zanemarljivo više skorove u odnosu na one iz druge. 
Jovana Jestrović i lvana Mihić

Tabela 3

Značajnost pripadanja određenoj grupi za percepciju podrške

\begin{tabular}{lllllll}
\hline & & Suma kvadrata & $d f$ & Prosek kvadrata & $F$ & $p$ \\
\hline \multirow{4}{*}{ porodica } & Između grupa & 17.05 & 2 & 8.53 & & \\
& Unutar grupa & 824.67 & 307 & 2.69 & 3.17 & .04 \\
& Total & 841.72 & 309 & & & \\
\multirow{5}{*}{ prijatelji } & Između grupa & 23.59 & 2 & 11.79 & & \\
& Unutar grupa & 835.68 & 307 & 2.72 & 4.33 & .01 \\
& Total & 859.67 & 309 & & & \\
\hline
\end{tabular}

Napomena. $d f$ - stepeni slobode; $F$ - vrednost F-testa, $p$ - nivo značajnosti.

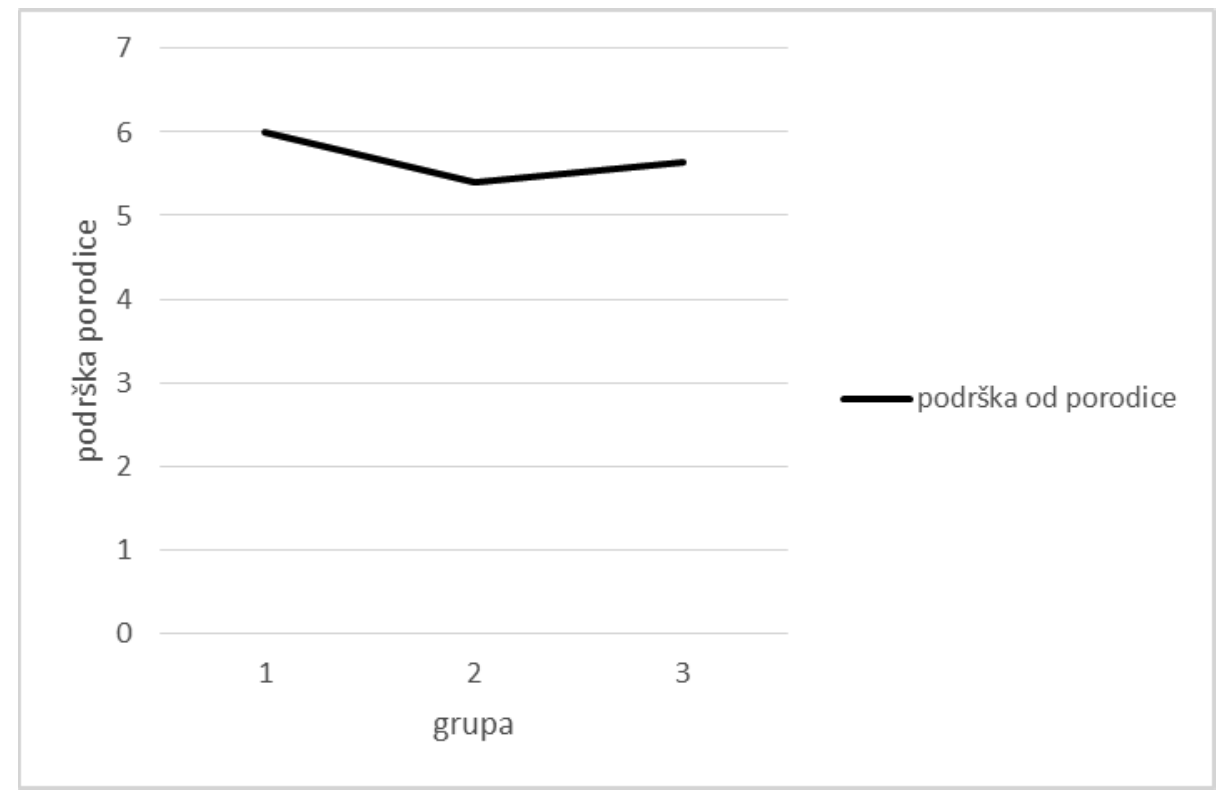

Grafik 1. Razlike među grupama žena koje se suočavaju sa neplodnošću u percipiranoj podršci od strane porodice 


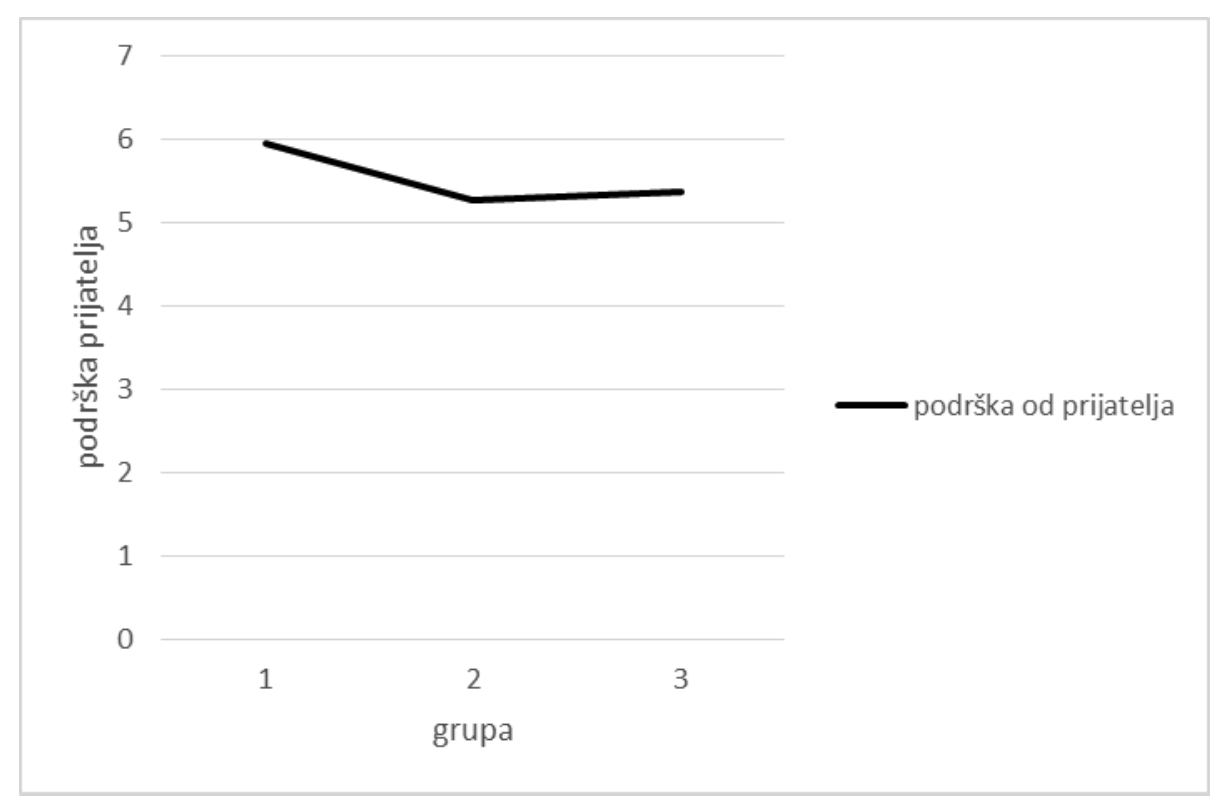

Grafik 2. Razlike među grupama žena koje se suočavaju sa neplodnošću u percipiranoj podršci od strane prijatelja

\section{Značajnost različitih izvora podrške u percepciji stresa povodom ne- plodnosti}

Da bi se ispitala značajnost različitih izvora podrške u percepciji globalnog stresa povodom neplodnosti, primenjena je višestruka regresiona analiza. Prema dobijenim rezultatima, testirani model je značajan, $F(3,286)=16.31, p$ $<.01$, a $14 \%$ varijanse stresa povodom neplodnosti se može objasniti percipiranom socijalnom podrškom iz različitih izvora.

Od varijabli iz prediktorskog skupa, značajnim se izdvajaju podrška prijatelja (kao najznačajnija) i podrška porodice, i to u negativnom smeru, dok podrška značajne osobe ne daje značajan doprinos predviđanju kriterijumske varijable, odnosno globalnog stresa povodom neplodnosti (Tabela 4). Dobijeni nalazi govore u prilog tome da, što ispitanice podršku dobijenu od prijatelja i porodice procenjuju većom, to će stres povodom neplodnosti procenjivati manje zastupljenim. 
Tabela 4

Značajnost doprinosa različitih izvora podrške u objašnjenju stresa povodom neplodnosti

\begin{tabular}{lccc}
\hline & $\beta$ & $t$ & $p$ \\
\hline Porodica & -.17 & -2.46 & .00 \\
Prijatelji & -.21 & -2.90 & .00 \\
Značajna osoba & -.06 & -0.74 & .46 \\
\hline
\end{tabular}

Napomena. $\beta$ - parcijalni doprinos prediktora; $t$ - vrednost t-testa; $p$ - nivo značajnosti.

Testirajući značajnost modela u kontekstu specifičnih aspekata stresa, rezultati ukazuju na to da je model značajan u predviđanju svih aspekata stresa, odnosno da se određeni procenat njegovih različitih aspekata može objasniti preko percipirane socijalne podrške iz različitih domena (Tabela 5).

Tabela 5

Pokazatelji relevantni za značajnost modela u predikciji različitih aspekata stresa kod žena koje se suočavaju sa neplodnošću

\begin{tabular}{lccc}
\hline & $R^{2}$ & $F$ & $p$ \\
\hline Socijalni aspekt & .21 & 25.91 & .00 \\
Seksualni aspekt & .14 & 16.53 & .00 \\
Partnerski odnos & .15 & 17.85 & .00 \\
Potreba za roditeljstvom & .03 & 3.07 & .03 \\
Odbijanje života bez dece & .03 & 3.16 & .03 \\
\hline
\end{tabular}

Napomena. $R^{2}$ - koeficijent multiple determinacije; $F$ - vrednost F-testa; $p$ - nivo značajnosti.

Posmatrajući značajnost pojedinačnih aspekata socijalne podrške, u predikciji socijalnog aspekta stresa značajnim se izdvajaju podrška porodice, $\beta=$ $-.24 ; \mathrm{t}=-3.48 ; \mathrm{p}<.01$, i podrška prijatelja, $\beta=-.37 ; \mathrm{t}=-5.22 ; \mathrm{p}<.01$, i to tako $\mathrm{da}$, što je ispitanice percipiraju višom, to je socijalni aspekt stresa povodom neplodnosti niži. Iste subskale izdvajaju se značajnim i u proceni seksualnog aspekta stresa (porodica: $\beta=-.22 ; \mathrm{t}=-3.18$; $\mathrm{p}<.01$; prijatelji: $\beta=-.17$; $\mathrm{t}=$ -2.35; $\mathrm{p}<.05$ ), takođe $\mathrm{u}$ negativnom smeru. U predikciji stresa iz domena partnerskog odnosa značajnim se izdvajaju podrška značajne osobe, $\beta=-.27$; $\mathrm{t}=$ $-3.41 ; \mathrm{p}<.01$, i porodice, $\beta=-.17 ; \mathrm{t}=-2.47 ; \mathrm{p}<.05$, pri čemu ispitanice koje ovu podršku percipiraju višom, stres u ovom domenu percipiraju manje izraženim. Iako je model značajan u celini, nijedna od njegovih pojedinačnih dimenzija se nije pokazala značajnim u predikciji potrebe za roditeljstvom i odbijanja života bez dece, a osvrnuvši se na rezultate prikazane u Tabeli 5 , vidi se da je procenat objašnjenje varijanse kriterijuma i u jednom i u drugom slučaju veoma nizak i iznosi svega 3\%. 


\section{Diskusija}

Budući da neplodnost predstavlja stres koji pogađa pojedinca i funkcionisanje unutar para (Burns \& Covington, 2006), te porodici onemogućava prelazak u narednu razvojnu fazu (Daly \& Kerry, 1999), na putu suočavanja sa njome ovi parovi se susreću sa brojnim negativnim emocijama visokog intenziteta, koje se svakodnevno smenjuju (Alesi, 2005). U stranim istraživanjima pokazano je da u ovom procesu suočavanja sa krizom značajnu ulogu ostvaruje socijalna podrška (npr. Martins et al., 2014). S obzirom na postojanje velikog broja parova koji se suočavaju sa ovim problemom u našoj zemlji i činjenicu da efekti socijalne podrške iz različitih izvora do sada nisu ispitivani (ispitivani su samo efekti podrške partnera na bračno funkcionisanje - Jestrović i sar., 2016), u radu prikazano istraživanje sprovedeno je sa ciljem ispitivanja značajnosti percipirane socijalne podrške od strane porodice, prijatelja i značajne osobe kao prediktora za procenu stresa povodom neplodnosti.

Ispitujući zastupljenost podrške iz različitih izvora, rezultati istraživanja su u skladu sa prethodno dobijenim visokim skorovima na socijalnoj podršci kod parova koji se suočavaju sa neplodnošću (Jirka et al., 1996). Na ispitanom uzorku žena najviše je zastupljena podrška značajne osobe, zatim porodice i na kraju prijatelja. Navedeni rezultat u skladu je sa rezultatima prethodnih istraživanja (Martins et al., 2011), a može se objasniti time da su žene neretko dominantno fokusirane na partnera i sa njim najviše razgovaraju o problemu (Woods et al., 1991), što dovodi do toga da ova vrsta podrške i bude ona koju percipiraju najzastupljenijom. Ispitanice izveštavaju o nešto nižoj zastupljenosti podrške od strane porodice, dok je podrška od prijatelja najmanje zastupljena. S obzirom na to da je u ovom istraživanju ispitan ženski uzorak, te da je neplodnost kriza koja u većoj meri menja socijalno funkcionisanje žena, nego što je to slučaj kod muškaraca (Leiblum, 1997), dobijeni nalazi se mogu time objasniti. Ipak, trebalo bi biti na oprezu sa tumačenjem rezultata budući da je i ovaj rezultat visok, te se ne radi o izostanku podrške od prijatelja (prosečna vrednost podrške dobijene od strane prijatelja je 5.5 na skali procene od 1 do 7). U istraživanjima iz drugih zemalja uočavaju se drugačiji rezultati ispitivana mreža podrške se doživljava manje dostupnom među ispitanicama iz Portugala (Martins et al., 2011) i Pakistana (Saleem et al., 2019). Navedeni rezultat može biti ohrabrujući i ukazivati na postojanje dobre mreže podrške ovim parovima, sa jedne strane, dok bi sa druge strane trebalo biti obazriv sa donošenjem zaključaka budući da se radi o samoproceni, te postoji mogućnost da su ispitanice davale socijalno poželjne odgovore. Kulturna specifičnost našeg okruženja može biti očekivanje o većoj prisutnosti podrške od strane bliskih ljudi, pa samim tim i percipirana viša dostupnost ovih resursa podrške. Upravo zbog navedenog bi trebalo, kako u narednim istraživanjima, tako i u praksi, pratiti realnu funkcionalnost i dostupnost ove mreže podrške.

Rezultati koji ukazuju na izostanak razlika među ispitanicama u percipiranoj podršci iz bilo kog od ispitanih izvora s obzirom na to ko je nosilac dijag- 
noze, mogu se razumeti kao da se neplodnost posmatra kao stres koji pogađa nivo para (Peterson et al., 2008) i da za suočavanje sa njim i za oslanjanje na dostupne resurse i podršku nije relevatno ko od partnera je nosilac dijagnoze (Greil et al., 2010). Ipak, kako bi se stekao potpuni uvid, neophodno bi bilo ispitati i muški deo uzorka. Dobijeni rezultati mogu se razumeti kao odraz posmatranja problema na dijadnom nivou, sa jedne strane, ali i posmatranja problema neplodnosti kao problema žene, u skladu sa i dalje dominantnim viđenjima u pojedinim društvima (Chan et al., 2006; Inhorn, 2003; Saleem et al., 2019). U skladu sa navedenim objašnjenjem je i rezultat koji ukazuje na to da je od svih aspekata stresa povodom neplodnosti najmanje zastupljen stres iz domena partnerskog odnosa. $\mathrm{S}$ obzirom na to da naša kultura spada $\mathrm{u}$ tradicionalne u kojima je i dalje osnovna uloga žene da bude majka (Kričković Pele i Beker, 2014), moguće da se zapravo radi o tome da žene ovaj problem i suočavanje sa njim preuzimaju na sebe, te ga drže izvan partnerskog odnosa. $\mathrm{U}$ prilog navedenom govori i podatak da su, iako je razlika u korist žena $\mathrm{u}$ domenu nosioca dijagnoze svega nekoliko procenata, žene te koje u više od polovine slučajeva iniciraju tretman, dok je procena žena da muškarci to rade u $1 \%$, a procena muškaraca u $2 \%$ slučajeva (Hjelmstedt et al., 1999). S obzirom na to da se kod parova koji ulaze u proces vantelesne oplodnje medicinske intervencije odvijaju na ženinom telu, bez obzira na to ko je nosilac dijagnoze (Pasch \& Christensen, 2000), kod žena se dodatno može povećati utisak da su one te koje imaju problem. Ipak, kako je podrška partnera na ispitanom uzorku visoko zastupljena, viša od ostala dva resursa, može se pretpostaviti da je u osnovi ovih rezultata posmatranje problema kao zajedničkog, dijadnog stresora koji pogađa funkcionisanje para i sa kojim se oni zajedno nose, bez obzira na to ko je nosilac dijagnoze.

Uzimajući u obzir grupu u kojoj se ispitanice nalaze, uočavaju se značajne razlike u percepciji podrške od prijatelja i porodice, ali ne i značajne osobe. Ukoliko pretpostavimo da je za većinu ispitanica značajna osoba partner, dobijeni nalazi su delimično očekivani, budući da su u skladu sa pretpostavkom o najvećoj usmerenosti partnera jedno na drugo i razgovaranju o problemu dominantno sa partnerom (Woods et al., 1991), i ukazuju na visoku prisutnost ove podrške, bez obzira na fazu tretmana. Sa druge strane, rezultati koji se odnose na podršku prijatelja i porodice su neočekivani. Iako je u nekim prethodnim studijama pokazano da socijalna podrška raste sa dužinom braka i suočavanja sa problemom (Ekinci et al., 2017), u sprovedenom istraživanju ispitanice iz prve grupe, odnosno one koje se sa problemom suočavaju najkraće, podršku od prijatelja i porodice percipiraju najzastupljenijom, značajno zastupljenijom od onih iz druge dve grupe, koje se bore sa neplodnošću duže od dve godine. Dobijeni nalazi potvrđuju pretpostavku o izolovanosti i otuđivanju parova od porodice porekla i prijatelja, usled osećanja različitosti (Peterson et al., 2012). Nadalje, dobijeni rezultati mogu biti tumačeni i u svetlu korišćenja različitih strategija prevladavanja u različitim momentima suočavanja sa ovim problemom. Sam početak suočavanja karakteriše reakcija šoka i neverice, koju sledi 
rad na prihvatanju problema, što potencijalno dovodi do većeg oslanjanja na podršku bliskih ljudi, usled veće potrebe za emotivnom podrškom (Burns \& Covington, 2006). Postoji mogućnost da su parovi nakon nekog perioda više posvećeni praktičnim aspektima problema i fokusirani na njegovo rešenje, odnosno tretman. Ovi rezultati svakako pozivaju na akciju u smislu isticanja značajnosti kontinuirane podrške, s obzirom na to da rezultati prethodnih studija ukazuju na povećanu potrebu za socijalnom podrškom sa dužinom suočavanja sa problemom (Jirka et al., 1996), a u ovom istraživanju dobijeni rezultati ukazuju da je ona najviše izražena u prvoj fazi tretmana. Svakako, za sticanje kompletnijeg uvida $u$ trend percipirane socijalne podrške potrebno je sprovesti longitudinalnu studiju u kojoj bi se iste ispitanice pratile kroz različite faze suočavanja. U ovom slučaju, sprovođenjem transverzalnog istraživanja, zaključci ostaju na nivou postojanja ili izostanka razlika među ženama koje se nalaze u različitim grupama.

Ispitivanjem efekata koje socijalna podrška primljena iz različitih izvora ostvaruje na globalni stres povodom neplodnosti dobijaju se neočekivani rezultati. Naime, podrška od strane prijatelja i porodice pokazala se značajnom, dok to nije slučaj sa podrškom značajne osobe, što je u suprotnosti sa rezultatima prethodnih istraživanja koja govore o podršci partnera kao najznačajnijem resursu prilikom suočavanja sa neplodnošću, značajnijem od podrške porodice porekla (Martins et al., 2014). Ispitujući efekat percipirane podrške na specifične aspekte stresa povodom neplodnosti, podrška od strane porodice i prijatelja pokazala se značajnom i u predikciji socijalnog i seksualnog aspekta stresa povodom neplodnosti, dok se podrška od strane značajne osobe izdvaja značajnom samo u objašnjenju partnerskog odnosa. Dobijeni nalazi govore u prilog tome da je kod žena koje se suočavaju sa neplodnošću podrška od strane partnera značajna u smanjenju stresa povezanog sa partnerskim odnosom, ali ne i sa drugim domenima stresa. Rezultati istraživanja delimično su potvrdili polazne pretpostavke, u domenu značajnosti podrške prijatelja i porodice $\mathrm{u}$ proceni stresa iz domena socijalnog, dok su u suprotnosti sa rezultatima prethodnih istraživanja koja ukazuju na značaj podrške partnera ne samo za procenu stresa u partnerskom domenu, već i onog koji se odnosi na domen seksualnog funkcionisanja (Martins et al., 2011). Rezultati koji ukazuju na to da podrška od strane značajne osobe nije značajna u objašnjenju globalnog nivoa stresa povodom neplodnosti mogu biti tumačeni u svetlu generalno visokih skorova na podršci, te toga da je možda ovaj vid podrške onaj koji se nekako „podrazumeva“ od strane žena koje se suočavaju sa ovim problemom, budući da je neplodnost zapravo partnerski problem, a ne problem pojedinca (Burns \& Covington, 2006). Na ispitanom uzorku najznačajnijom podrškom u predikciji globalnog stresa povodom neplodnosti pokazala se ona koju dobijaju od prijatelja, koja je, zapravo, najmanje zastupljena. Dobijeni nalaz u suprotnosti je sa rezultatima prethodnih studija, od kojih se u nekima ovaj resurs podrške čak ni ne pokazuje značajnim, ni kod muškaraca, ni kod žena (Martins et al., 2014). Potencijalno objašnjenje dobijenih rezultata može se tražiti u 
činjenici da je na ispitanom uzorku ova podrška najmanje zastupljena, te kao takva najviše okupira pažnju ispitanica i ostvaruje najveći udeo u objašnjenju stresa. Podrška od strane porodice izdvaja se značajnom kako u predikciji globalnog nivoa stresa, tako i u njegovom socijalnom, seksualnom i partnerskom domenu. Značajnost podrške od strane porodice očekivana je i u skladu sa prethodnim studijama, čiji rezultati ukazuju na postojanje povezanosti i želje žena da o problemu neplodnosti razgovaraju sa svojom porodicom (Cousineau \& Domar, 2007). Kao smernica za naredna istraživanja bilo bi važno ispitati ovaj efekat na muškarcima, budući da oni najčešće traže podršku u suočavanju sa problemom zajedno sa suprugama i ne ostvaruju tolike benefite od socijalne podrške koji su pronađeni kod žena (Peterson et al., 2006).

\section{Praktične implikacije}

Uzimajući u obzir činjenicu da je podrška od strane prijatelja najvažniji faktor u smanjenju stresa povodom neplodnosti, kao i to da se podrška porodice takođe pokazala značajnom, dobijaju se smernice za bavljenje ovim problemom na opštem nivou. Dobijeni nalazi govore u prilog potrebe za edukacijom opšte populacije o problemu neplodnosti, njegovoj zastupljenosti i načinima na koje svako može biti podrška ljudima koji se suočavaju sa ovim problemom. Na ovaj način pruža se mogućnost da parovi koji se suočavaju sa ovim problemom dobiju podršku od bliskih ljudi koju smatraju adekvatnom i koja će doprineti tome da stres povodom problema bude manje zastupljen, te tako doprineti kvalitetu njihovog mentalnog (Saleem et al., 2019), pa i fizičkog zdravlja (Welbourne et al., 2009). Sa druge strane, s obzirom da je važan segment dobijanja podrške koju procenjujemo korisnom zapravo traženje iste, dobijeni rezultati govore i o važnosti edukovanja parova koji se suočavaju sa neplodnošću o funkcionalnim načinima traženja podrške od bliskih ljudi. Navedeno je posebno značajno u kontekstu rezultata koji govore u prilog tome da žene koje su na početku suočavanja sa problemom podršku procenjuju najvišom, dok one koje se više od dve godine bore sa neplodnošću ovu podršku procenjuju značajno nižom. U tom smislu, važno je osvestiti značaj prisustva kontinuirane i adekvatne socijalne podrške, kako kod opšte populacije, tako i kod parova koji se suočavaju sa ovom krizom.

Nadalje, iako se nije pokazala značajnom u određenju generalnog stresa povodom neplodnosti, podrška od strane partnera značajna je za snižavanje stresa iz ovog domena, te je stoga važno sa parovima zajedno raditi i na učenju tehnika traženja i pružanja podrške unutar partnerskog odnosa. Osim toga, ovaj rezultat predstavlja značajnu smernicu i za stručnjake iz medicinskog konteksta koji rade sa parovima koji se suočavaju sa neplodnošču, tako da se što više trude da parove zajedno uključuju u čitav proces tretmana i neplodnost posmatraju kao problem para (Johnson \& Johnson, 2009), budući da se podrška od strane partnera ogleda u razgovaranju o problemu, slušanju i ra- 
zumevanju, ali i praćenju partnerke do klinike i uključenosti u tretman (Pasch \& Christensen, 2000).

\section{Reference}

Abraham, A. D. (2019). Perceptions of social support in infertility (Unpublished doctoral dissertation). Chestnut Hill College.

Alesi, R. (2005). Infertility and its treatment: An emotional roller coaster. Australian Family Physician, 34(3), 135-138.

Burns, L. H., \& Covington, S. N. (2006). Psychology of infertility. In S. N. Covington \& L. H. Burns (Eds.), Infertility counseling: A comprehensive handbook for clinicians (pp. 1-19). The Cambridge University Press. https://doi. org/10.1017/CB09780511547263.003

Canty-Mitchell, J., \& Zimet, G. D. (2000). Psychometric properties of the Multidimensional Scale of Perceived Social Support in urban adolescents. American Journal of Community Psychology, 28(3), 391-400. https://doi. org/10.1023/A:1005109522457

Chan, C. H. Y., Ng, E. H. Y., Chan, C. L. W., Ho, P. C., \& Chan, T. H. Y. (2006). Effectiveness of psychosocial group intervention for reducing anxiety in women undergoing in vitro fertilization: A randomized controlled study. Fertility and Sterility, 85(2), 339-346. https://doi.org/10.1016/j. fertnstert.2005.07.1310

Cousineau, T. M., \& Domar, A. D. (2007). Psychological impact of infertility. Best Practice \& Research Clinical Obstetrics \& Gynaecology, 21(2), 293-308. https://doi.org/10.1016/j.bpobgyn.2006.12.003

Daly, K. J., \& Kerry, J. (1999). Crisis of Genealogy: Facing the Challenges of Infertility. In H. I. McCubbin, E. A. Thompson, A. I. Thompson, \& J. Futrell (Eds.), Dynamics of Resilient Families (pp. 1-40). Sage Publications.

Ekinci, F., Tuncel, B., Uzuner, A., Anğın, A. D., Çoşkun, D. M., Sakin, Ö., Çıkman, M. S., \& Şimşek, E. E. (2017). An evaluation of the psychosocial status of infertile women. Southern Clinics of Istanbul Eurasia, 28, 4-7. https://doi. org/ 10.14744/scie.2017.83007

Gerrity, D. A. (2001). Five Medical Treatment Stages of Infertility: Implications for Counselors. The Family Journal: Counseling and Therapy for Couples and Families, 9(2), 140-150. https://doi.org/10.1177/1066480701092008

Greil, A. L., Slauson-Blevins, K., \& McQuillan, J. (2010). The experience of infertility: A review of recent literature. Sociology of Health \& Illness, 32(1), 140-162. https://doi.org/10.1111/j.1467-9566.2009.01213.x

Hinton, L., Kurinczuk, J. J., \& Ziebland, S. (2010). Infertility; isolation and the Internet: A qualitative interview study. Patient Education and Counseling, 81(3), 436-441. https://doi.org/10.1016/j.pec.2010.09.023

Hjelmstedt, A., Andersson, L., Skoog-Svanberg, A., Bergh, T., Boivin, J., \& Collins, A. (1999). Gender differences in psychological reactions to infertility 
among couples seeking IVF-and ICSI-treatment. Acta Obstetricia et Gynecologica Scandinavica, 78(1), 42-49. https://doi.org/10.1034/j.16000412.1999.780110.x

Inhorn, M. C. (2000) Missing motherhood: Infertility, technology, and poverty in Egyptian women's lives. In H. Ragone \& F. Widdance-Twine (Eds.), Ideologies and technologies of motherhood (pp. 139-168). Routledge.

Jestrović, J., Mihić, I. i Radovanović, M. (2016). Tranzicija u roditeljstvo: razlike u kvalitetu braka parova koji su začeli prirodnim putem i onih koji su začeli vantelesnom oplodnjom. Godišnjak za psihologiju, 13(15), 55-69.

Jirka, J., Schuett, S., \& Foxall, M. J. (1996). Loneliness and social support in infertile couples. Journal of Obstetric, Gynecologic, \& Neonatal Nursing, 25(1), 55-60. https://doi.org/10.1111/j.1552-6909.1996.tb02513.x

Johnson, K. M., \& Johnson, D. R. (2009). Partnered decisions? US couples and medical help-seeking for infertility. Family Relations, 58(4), 431-444. https://doi.org/10.1111/j.1741-3729.2009.00564.x

Knight, R. G., Chisholm, B. J., Marsh, N. V., \& Godfrey, H. P. (1988). Some normative, reliability, and factor analytic data for the revised UCLA Loneliness Scale. JournalofClinicalPsychology,44(2),203-206.https://doi.org/10.1002/10974679(198803)44:2<203::AID-JCLP2270440218>3.0.CO;2-5

Kričković Pele, K. i Beker, K. (2014). Rodne i društvene kontroverze vantelesne oplodnje u Srbiji - diskriminacija žena koje nisu rađale. Temida, 17(3), 4968. https://doi.org/10.2298/TEM1403049K

Kroemeke, A., \& Kubicka, E. (2018). Positive and negative adjustment in couples undergoing infertility treatment: The impact of support exchange. PloS One, 13(6), 1-12. https://doi.org/10.1371/journal.pone.0200124

Leiblum, S. R. (1997). Infertility psychological issues and counseling strategies. Wiley.

Martins, M. V., Peterson, B. D., Almeida, V. M., \& Costa, M. E. (2011). Direct and indirect effects of perceived social support on women's infertility-related stress. Human Reproduction, 26(8), 2113-2121. https://doi.org/10.1093/ humrep/der157

Martins, M. V., Peterson, B. D., Almeida, V., Mesquita-Guimaraes, J., \& Costa, M. E. (2014). Dyadic dynamics of perceived social support in couples facing infertility. Human Reproduction, 29(1), 83-89. https://doi.org/ 10.1093/ humrep/det403

Matsubayashi, H., Hosaka, T., Izumi, S., Suzuki, T., Kondo, A., \& Makino, T. (2004). Increased depression and anxiety in infertile Japanese women resulting from lack of husband's support and feelings of stress. General Hospital Psychiatry, 26(5), 398-404. https://doi.org/10.1016/j.genhosppsych.2004.05.002

Newton, C. R., Sherard, W., \& Glavac, I. (1999). The Fertility Problem Inventory: measuring perceived infertility-related stress. Fertility and Sterility, 72(1), 54-62. https://doi.org/10.1016/S0015-0282(99)00164-8

Pasch, L. A., \& Christensen, A. (2000). Couples facing fertility problems. In K. B. Schmaling \& T. G. Sher (Eds.), The psychology of couples and illness: Theory, 
research, \& practice (pp. 241-267). American Psychological Association. https://doi.org/10.1037/10360-009

Peterson, B. D., Newton, C. R., Rosen, K. H., \& Skaggs, G. E. (2006). Gender differences in how men and women who are referred for IVF cope with infertility stress. Human Reproduction, 21(9), 2443-2449. https://doi. org/10.1093/humrep/del145

Peterson, B. D., Pirritano, M., Christensen, U., \& Schmidt, L. (2008). The impact of partner coping in couples experiencing infertility. Human Reproduction, 23(5), 1128-1137. https://doi.org/10.1093/humrep/den067

Peterson, B., Boivin, J., Norre, J., Smith, C., Thorn, P., \& Wischmann, T. (2012). An introduction to infertility counseling: a guide for mental health and medical professionals. Journal of Assisted Reproduction \& Genetics, 29(3), 243-248. https://doi.org/10.1007/s10815-011-9701-y

Saleem, S., Qureshi, N. S., \& Mahmood, Z. (2019). Attachment, perceived social support and mental health problems in women with primary infertility. International Journal of Reproduction, Contraception, Obstetrics and Gynecology, 8(6), 2533-2540. https://doi.org/ 10.18203/2320-1770. ijrcog20192463

Schwarzer, R., \& Knoll, N. (2007). Functional roles of social support within the stress and coping process: A theoretical and empirical overview. International Journal of Psychology, 42(4), 243-252. https://doi. org/10.1080/00207590701396641

Slade, P., O'Neill, C., Simpson, A. J., \& Lashen, H. (2007). The relationship between perceived stigma, disclosure patterns, support and distress in new attendees at an infertility clinic. Human Reproduction, 22(8), 2309-2317. https://doi. org/10.1093/humrep/dem115

Vassard, D., Lund, R., Pinborg, A., Boivin, J., \& Schmidt, L. (2012). The impact of social relations among men and women in fertility treatment on the decision to terminate treatment. Human Reproduction, 27(12), 3502-3512. https:// doi.org/10.1093/humrep/des353

Walen, H. R., \& Lachman, M. E. (2000). Social support and strain from partner, family, and friends: Costs and benefits for men and women in adulthood. Journal of Social and Personal Relationships, 17(1), 5-30. https://doi. org/10.1177/0265407500171001

Welbourne, J. L., Blanchard, A. L., \& Boughton, M. D. (2009). Supportive communication, sense of virtual community and health outcomes in online infertility groups. Proceedings of the Fourth International Conference on Communities and Technologies, 31-40. https://doi. org/10.1145/1556460.1556466

Woods, N., Olshansky, E., \& Draye, M. (1991). Infertility: Women's experiences. Health Care for Women International, 12(2), 179-189. https://doi. org/10.1080/07399339109515939

Ying, L. Y., Wu, L. H., \& Loke, A. Y. (2015). Gender differences in experiences with and adjustments to infertility: A literature review. International 
Journal of Nursing Studies, 52(10), 1640-1652. https://doi.org/10.1016/j. ijnurstu.2015.05.004

Zegers-Hochschild, F., Adamson, G. D., de Mouzon, J., Ishihara, O., Mansour, R., Nygren, K., Sullivan, E., van der Poel, \& WHO. (2009). The International Committee for Monitoring Assisted Reproductive Technology (ICMART) and the World Health Organization (WHO) Revised Glossary on ART Terminology, 2009. Human Reproduction, 24(11), 2683-2687. https://doi.org/10.1093/ humrep/dep343

Zimet, G. D., Powell, S. S., Farley, G. K., Werkman, S., \& Berkoff, K. A. (1990). Psychometric Characteristics of the Multidimensional Scale of Perceived Social Support. Journal of Personality Assessment, 55(3/4), 610-617. https:// doi.org/10.1080/00223891.1990.9674095 


Jovana Jestrović
Center for
enhancement and
support for early
development and
family relations -
„Harmony“, Novi
Sad
Ivana Mihić
Department of
Psychology, Faculty
of Philosophy,
University of Novi
Sad

Jovana Jestrović

Center for

enhancement and

support for early development and family relations „Harmony“, Novi

\section{SOCIAL SUPPORT AND INFERTILITY STRESS: THE SIGNIFICANCE OF DIFFERENT SOURCES OF SUPPORT}

The results of previous studies indicate the importance of social support for an individual's quality of life. Social support stands out as one of the most important protective factors in the process of coping with numerous life crises and infertility is one of them. In order to examine the significance of the social support received by friends, family and significant other in the perception of infertility stress, 312 infertile women, aged 21 to 48, were asked to complete the Multidimensional Scale of Perceived Social Support and the Fertility Problem Inventory. Respondents rate the social support they receive from their loved ones very high for every source of support, with the highest score for support from a significant person, then family and friends. Significant differences were found between women from different groups / lengh of facing with the problem in the perception of support by family and friends, but not by partners. Regardless of results that show the highest support from a partner, regression analysis showed that the explanation of perceived infertility stress variance was significantly determined by support from friends and family, whereas support from a significant person did not prove to be a significant predictor, except in the domain of relationship stress. The findings highlight the importance of educating the general population about the problem of infertility and about ways how to support these couples, as well as working with individuals and couples who are facing infertility to develop adaptive strategies for seeking support from their close ones.

Key words: family, friends, infertility, partner, social support 